\title{
Aspiration versus peritoneal lavage in appendicitis: a meta-analysis
}

\author{
Gloria Burini ${ }^{* *}$ D, Maria Chiara Cianci ${ }^{2}$, Marco Coccetta ${ }^{3}$, Alessandro Spizzirri ${ }^{3}$, Salomone Di Saverio ${ }^{4}$, \\ Riccardo Coletta ${ }^{5}$, Paolo Sapienza ${ }^{6}$, Andrea Mingoli $^{6}$, Roberto Cirocchi ${ }^{7}$ and Antonino Morabito ${ }^{8}$
}

\begin{abstract}
Background: Acute appendicitis is one of the most frequent abdominal surgical emergencies. Intra-abdominal abscess is a frequent post-operative complication. The aim of this meta-analysis was to compare peritoneal irrigation and suction versus suction only when performing appendectomy for complicated appendicitis.

Methods: According to PRISMA guidelines, a systematic review was conducted and registered into the Prospero register (CRD42020186848). The risk of bias was defined to be from low to moderate.

Results: Seventeen studies (9 RCTs and 8 CCTs) were selected, including 5315 patients. There was no statistical significance in post-operative intra-abdominal abscess in open (RR 1.27, 95\% Cl 0.75-2.15; $1^{2}=74 \%$ ) and laparoscopic group (RR 1.51, 95\% Cl 0.73-3.13; $P^{2}=83 \%$ ). No statistical significance in reoperation rate in open (RR $1.27,95 \% \mathrm{Cl} 0.04-2.49$; $P^{2}=18 \%$ ) and laparoscopic group (RR 1.42,95\% Cl 0.64-2.49; $l^{2}=18 \%$ ). In both open and laparoscopic groups, operative time was lower in the suction group (RR 7.13,95\% Cl 3.14-11.12); no statistical significance was found for hospital stay (MD $-0.39,95 \% \mathrm{Cl}-1.07$ to $0.30 ; I^{2}=91 \%$ ) and the rate of wound infection (MD 1.16, 95\% Cl 0.56-2.38; $\left.P^{2}=71 \%\right)$.

Conclusions: This systematic review has failed to demonstrate the statistical superiority of employing intra-operative peritoneal irrigation and suction over suction-only to reduce the rate of post-operative complications after appendectomy, but all the articles report clinical superiority in terms of post-operative abscess, wound infection and operative times in suction-only group.
\end{abstract}

Keywords: Complicated appendicitis, Post-operative intra-abdominal abscess, Peritoneal irrigation, Abscess suction

\section{Background}

Acute appendicitis is one of the most frequent abdominal surgical emergencies. It occurs with a rate of $8.6 \%$ for males and $6.7 \%$ for females [1]. Approximately $8 \%$ of the population will undergo appendectomy for acute appendicitis in their lifetime [2]. Complicated appendicitis represents from 14 to $55 \%$ of all appendicitis cases and is defined as an acute appendicitis with peritonitis, rupture, gangrene or intra-abdominal abscess, intraperitoneal presence of faecalith, intra-operative mass

\footnotetext{
*Correspondence: globur@libero.it

${ }^{1}$ General and Emergency Surgical Clinic of Ancona, Ancona, Italy

Full list of author information is available at the end of the article
}

or four-quadrant purulent material, local or generalized peritonitis $[3,4]$. Some studies have demonstrated that complicated appendicitis is associated with higher rates of major post-operative complications [5-8]. In children, perforated appendicitis has an incidence from 15 to $20 \%$ [7] and can be responsible for post-operative morbidity [1], especially related to post-operative IAA. In particular, perforated appendicitis leads more frequently to IAA [8-10], increasing the risk of surgical site infection, hospital stay and cost. The rate of IAA after appendectomy for perforated appendicitis is variable: some studies report between 5 and $10 \%$, others $3-20 \%[9,10]$. Perforated appendicitis was recognized as an independent risk factor for development of post-operative IAA [7-9]. Different studies defined a risk of post-operative IAA of original author(s) and the source, provide a link to the Creative Commons licence, and indicate if changes were made. The images or other third party material in this article are included in the article's Creative Commons licence, unless indicated otherwise in a credit line to the material. If material is not included in the article's Creative Commons licence and your intended use is not permitted by statutory regulation or exceeds the permitted use, you will need to obtain permission directly from the copyright holder. To view a copy of this licence, visit http://creativecommons.org/licenses/by/4.0/. The Creative Commons Public Domain Dedication waiver (http://creativeco mmons.org/publicdomain/zero/1.0/) applies to the data made available in this article, unless otherwise stated in a credit line to the data. 
$1-4 \%$ in non-perforated appendicitis [7-9], compared with $10-24 \%$ after appendectomy for perforated appendicitis $[9,10]$. Diabetes mellitus, young and old age [6], obesity and peritoneal irrigation were associated risk factors $[6,8]$.

Laparoscopic appendectomy has become the standard surgical procedure for acute appendicitis in both the paediatric and adult population [6,11-13]. Recognized benefits are a more rapid recovery, less pain, fewer wound infections, shorter hospitalization and earlier return to daily activities $[6,11,14,15]$. Although appendectomy is considered a safe procedure, different post-operative complications may occur, such as intra-abdominal abscess (IAA), wound infection, bleeding and bowel obstruction.

Most frequent and fearsome complication is abscess that occurs in $2.2 \%$ after laparoscopic appendectomy [16], but in both laparoscopic and open techniques, intra-abdominal abscess seems to be frequent, regardless of the technique. Its incidence is related especially to the severity of the appendicitis; patients with complicated appendicitis are more likely to develop an IAA regardless of technique $[16,17]$. In the paediatric population, the incidence of post-operative intra-abdominal abscess after appendectomy for complicated/perforated appendicitis is approximately $24 \%$ [9]. Abscess development is most frequently observed in perforated appendicitis [7, 10], which represents the main risk factor for this complication to occur [7-9].

Post-operative IAA is associated with $[1,18]$ significant morbidity, patient discomfort, prolonged hospital stay and increased cost, often necessitating readmission and repeat intervention [7, 19-22].

The management of IAA remains controversial with different strategies suggested to decrease its incidence: antibiotic prophylaxis [23, 24], post-operative antibiotic therapy [25], peritoneal irrigation with saline solution [26] or suction only of the abscess/purulent liquid without irrigation of the cavity during appendectomy. In the literature, many studies address this topic; however, currently there is no evidence to clearly demonstrate the effectiveness of peritoneal irrigation over suction only. Italian guidelines recommend thorough peritoneal lavage (6-8 L of warm saline) and aspiration to minimize the IAA rate in complicated appendicitis [27]. The recent WSES (World Society of Emergency Surgery) guidelines report that "Peritoneal irrigation does not have any advantage over suction alone in complicated appendicitis in both adults and children. The performance of irrigation during laparoscopic appendectomy does not seem to prevent the development of IAA and wound infections in neither adults nor paediatric patients". WSES recommendation is "to perform suction only in complicated appendicitis patients with intra-abdominal collections undergoing laparoscopic appendectomy" [QoE: Moderate; Strength of recommendation: Strong; 1B]) [28]. The concern regarding irrigation and lavage is that these procedures might help spread the infectious material [29]. This systematic review of the literature aims to evaluate the available data on comparative studies regarding peritoneal irrigation and suction vs suction only when performing appendectomy for complicated appendicitis.

\section{Main text \\ Methods}

This systematic review adheres to AMSTAR 2 criteria and examines the available data on comparative studies about irrigation and suction vs suction only during appendectomy [30].

The literature was searched using PubMed, Scopus and Web of Science up to 10 February 2021 including the following terms: "peritoneal irrigation" OR "peritoneal lavage" combined with "ruptured appendicitis" OR "perforated appendicitis".

No language restrictions were enforced. All titles and abstracts were analysed to select the studies that reported intra-operative lavage during appendectomy. To avoid duplication of data, only the most recent review was considered in case of overlapping study periods for articles performed by the same research groups.

The Preferred Reporting Items for Systematic Reviews and Meta-analyses (PRISMA) guidelines were followed [31].

The PubMed function "related articles" was used to expand each search and the reference list of all potentially eligible studies was evaluated. Full texts were then independently screened by two authors (S.V. and R.C.), and a final consensus was reached by the same authors. No disagreements were reported.

For each study, the following data were extracted and summarized: author's surname, year of publication, country of the hospital in which the procedures were performed, time of patient enrolment, study design, number of patients who underwent appendectomy, number of patients who underwent lavage and suction and suction only, age of patients, BMI, gender, severity of appendicitis and volume of peritoneal irrigation.

Primary outcomes were identified for both groups (irrigation and suction vs suction only) for laparoscopic and open appendectomy:

- Post-operative abdominal abscess.

- Reoperation for abdominal abscess.

The following data were considered as secondary outcomes: 
- Duration of surgical treatment.

- Length of stay.

- Wound infections.

A subgroup analysis was also performed distinguishing the RCTs and CCTs (controlled clinical trials).

Assessment of methodological quality was performed independently by two authors. The risk of bias in the RCTs was assessed using methods described in the Cochrane Handbook for Systematic Reviews of Interventions [32] and the Risk of Bias In Non-randomized Studies of Interventions (ROBINS-I) assessment tool $[33,34]$. Review questions and aims, outcomes, relevant confounding domains and co-interventions that could impact outcomes were assessed.

The systematic review and meta-analysis was registered into the Prospero international prospective register of systematic reviews (CRD42020186848).

Statistical analysis was performed with the Review Manager (RevMan version 5.3.5) computer program (Copenhagen: The Nordic Cochrane Centre, The Cochrane Collaboration, 2014).

Dichotomous outcomes were pooled with a randomeffects model applying the Mantel-Haenszel method to estimate risk ratios (RR) and their 95\% confidence intervals [35]. Clinical heterogeneity was tested using $\tau^{2}$, Cochrane's Q and $I^{2}$ statistics. An $I^{2}$ value exceeding 50\% was considered indicative for heterogeneity.

The random-effects analysis model was used for high clinical heterogeneity and statistically significant higher Chi-squared value and $I^{2}$ [36]. In all remaining circumstances, the fixed-effects model was applied [37].

\section{Results}

An initial literature search based on the evaluation of title and abstract yielded 841 reviews, and the results of searches are reported in Additional file 1: SDC searches.

Of them, 30 articles (including duplicated studies, case reports, articles without related data, review and metaanalysis publication) did not meet the inclusion criteria. The full text of 28 papers was reviewed: 11 studies were excluded (Additional file 2: Table S1) [19, 38-47] and 17 were selected for the meta-analysis $[4,6,8,10,48-60]$, according to PRISMA flow diagram (Fig. 1).

The 17 selected studies (9 RCTs and 8 CCTs) included 5315 patients (2532 irrigation and suction versus 2783 irrigation) (Table 1).

All studies were published between 1975 and 2020 and written in English language. One review did not report patients' age [6], eight studies were performed in paediatric patients and the other eight were performed in adults.

The average age in the washing and aspiration cohort ranged from 8.8 to 10.4 years for the paediatric subgroup and from 25.7 to 42 years for adults. In the suction alone cohort, instead, the relative average ages ranged from 9.1 to 10.9 years (paediatric patients) and from 20 to 44 years (adult subgroup). The characteristics of patients are reported in Additional file 3: SDC baseline.

\section{Quality assessment of RCTs}

No data about random sequence generation were reported in $44.4 \%$ of the RCTs (four studies) and no data about allocation concealment in $33.3 \%$ of the RCTs (three studies).

A "low risk of bias" was reported in the analysis of the attrition bias, and an "unclear risk of bias" was identified for selective reporting (Additional file 4: SDC 3a, Additional file 5: SDC $3 \mathrm{~b}$ ). The risk of bias of random sequence generation and allocation concealment was low.

\section{Quality assessment of non-RCTs}

According to ROBINS-I tool, risk-of-bias judgement may be identified as few, moderate, serious or critical. Three out of eight studies were assessed as low risk of overall bias, while five were determined to have a moderate risk. Regarding bias due to confounding, four out of eight studies were evaluated as having a low risk since authors used an appropriate analysis method that checked for all the relevant confounding domains. Furthermore, intervention discontinuations related to factors that are prognostic for the outcomes were not identified. On the other hand, four out of eight studies seemed to have a moderate risk of bias due to confounding (Additional file 6: SDC 4). Regarding bias in classification of the interventions, all studies had a low risk: intervention groups were clearly identified and they were not affected by knowledge of the outcome. Outcomes were clearly defined and measures were not influenced by knowledge of the intervention received. The methods of outcome assessment were comparable across intervention groups and no systematic errors were detected. Analysing bias due to missing data, three reviews were assessed as moderate risk.

\section{Results of effects of interventions Primary outcomes \\ Post-operative abdominal abscess after appendectomy}

In the groups considering both open and laparoscopic approaches, intra-abdominal abscess was reported in 5315 patients (17 studies). The rate of this complication was lower in patients who underwent suction only, but the result was not statistically significant (RR 1.23, 95\% CI 0.73-2.07; $I^{2}=72 \%$ ) (Fig. 2a). A further analysis was performed after the exclusion of Normann's article, published in the 1975, but the same non-statistically significant result was obtained (RR 1.27, 95\% CI 0.75-2.15; $\left.I^{2}=74 \%\right)$. Furthermore, an analysis of the RCTs (1725 


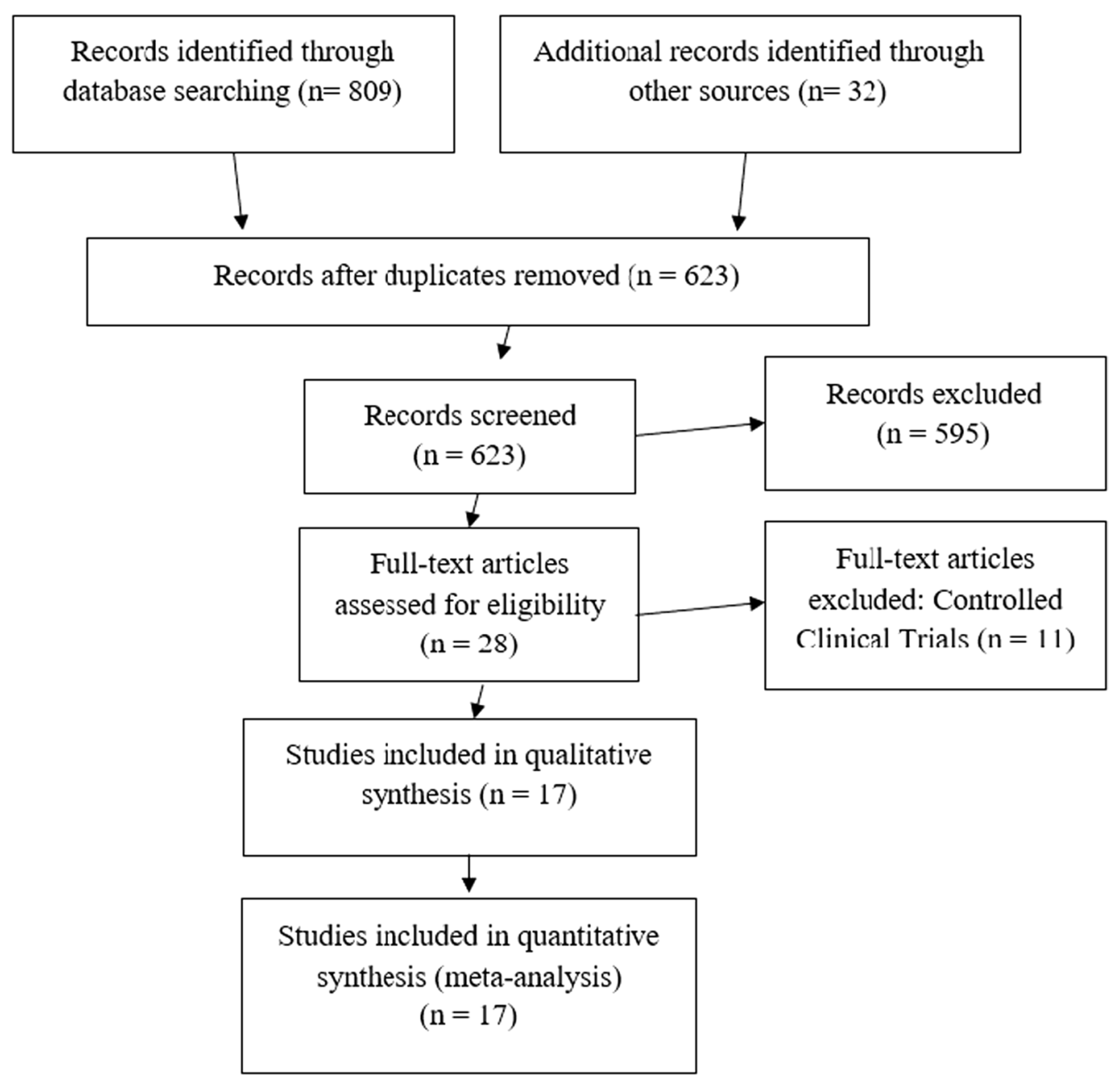

Fig. 1 PRISMA flow diagram

patients in 9 studies) was completed: the rate of abscess was lower in patients who underwent suction only, but the result was not statistically significant although the heterogeneity in this group was lower (RR 1.01, 95\% CI $0.66-1.55 ; I^{2}=31 \%$ ) (Fig. 2b).

The same outcomes were also reported in the laparoscopic approach group (4221 patients in 10 studies): the rate of abscess was lower in patients who underwent suction only, but the result was not statistically significant (RR 1.51, 95\% CI 0.73-3.13; $I^{2}=83 \%$ ) (Fig. 2c). The subgroup analysis of RCTs also showed same findings (RR 0.94, 95\% CI 0.61-1.45; $I^{2}=83 \%$ ) (Fig. 2d).

\section{Reoperation for post-operative abdominal abscess after appendectomy}

In the open and laparoscopic group, reoperation for post-operative abscess was reported in 1747 patients (8 studies) and a lower rate was registered in patients who underwent suction only; however, the results were not statistically significant (RR 1.27, 95\% CI 0.04-2.49; $I^{2}=18 \%$ ) (Fig. 3a). An analysis of the RCTs (639 patients in 5 studies) was performed. All the RCTs described a laparoscopic approach and the rate of abscess was also lower in patients who underwent suction only. The data were not statistically significant although there was no heterogeneity (RR 1.59, 95\% CI $2.73-1.55 ; I^{2}=0 \%$ ) (Fig. 3b).

In the laparoscopic group, reoperation was reported in 1458 patients (six studies). The rate of this complication was also lower in patients who underwent suction only, but the result was not statistically significant (RR 1.42, 95\% CI 0.64-2.49; $I^{2}=18 \%$ ) (Fig. 3c).

\section{Secondary outcome Operative time}

In the open and laparoscopic groups, operative time was evaluated in 2047 patients (6 studies) and was reported as significantly lower in patients who underwent suction 
Table 1 Characteristics of the RCT and observational studies included

\begin{tabular}{|c|c|c|c|c|c|c|}
\hline Study & Nation & Type of study & Time of enrolment & $\begin{array}{l}\text { Number } \\
\text { of patients } \\
\text { enrolled }\end{array}$ & Irrigation and suction & Suction \\
\hline Gemici 2020 & Turkey & $\mathrm{RCT}$ & 2014-2017 & 286 & $112(39.2 \%)$ & $174(60.8 \%)$ \\
\hline Anderson 2020 & Texas & $\mathrm{RCT}$ & $2016-2017$ & 100 & $50(50 \%)$ & $50(50 \%)$ \\
\hline Nataraja 2019 & Australia, China & $\mathrm{RCT}$ & 2015-2018 & 86 & $44(51.2 \%)$ & $42(48.8 \%)$ \\
\hline Lee 2019 & Korea & CCT & 2014-2016 & 553 & $207(37.4 \%)$ & $346(62.6 \%)$ \\
\hline Escolino 2018 & $\begin{array}{l}\text { Italy France, United King- } \\
\text { dom, Austria, Missouri }\end{array}$ & $\mathrm{CCT}$ & Over 5 years & 699 & $488(69.8 \%)$ & $211(30.2 \%)$ \\
\hline Sardiwalla 2018 & South Africa & $\mathrm{RCT}$ & $2016-2017$ & 86 & $42(48.8 \%)$ & $44(51.2 \%)$ \\
\hline Sun 2017 & China & $\mathrm{RCT}$ & 2015-2016 & 260 & $130(50 \%)$ & $130(50 \%)$ \\
\hline Snow 2016 & Australia & $\mathrm{RCT}$ & 2013-2015 & 81 & $40(49.4 \%)$ & $41(50.6 \%)$ \\
\hline Cho 2015 & Korea & CCT & 2010-2013 & 1817 & 731 (40.2\%) & $1086(59.8 \%)$ \\
\hline Hartwich 2013 & USA & CCT & $2005-2011$ & 237 & $139(58,6 \%)$ & $98(41,4 \%)$ \\
\hline St. Peter 2012 & USA & $\mathrm{RCT}$ & $2008-2011$ & 220 & $110(50 \%)$ & $110(50 \%)$ \\
\hline Akkoyun 2012 & Turkey & CCT & 1998-2011 & 234 & $61(26.1 \%)$ & $173(73.9 \%)$ \\
\hline Moore 2011 & USA & CCT & $2007-2008$ & 176 & 115 (65.3\%) & $61(34.7 \%)$ \\
\hline Toki 1995 & Japan & $\mathrm{RCT}$ & 1984-1993 & 53 & $29(54.7 \%)$ & $24(45.3 \%)$ \\
\hline Buanes 1991 & Norway & $\mathrm{RCT}$ & 1984-1987 & 83 & 39 (47\%) & 44 (53\%) \\
\hline Stewart 1978 & Great Britain & $\mathrm{CCT}$ & 1965-1974 & 189 & 117 (61.9\%) & $72(38.1 \%)$ \\
\hline Normann 1975 & Norway & CCT & 1968-1973 & 155 & $78(50.3 \%)$ & 77 (49.7\%) \\
\hline
\end{tabular}

$R C T$ randomized controlled trial, $C C T$ controlled clinical trial

only (RR 6.62, 95\% CI 4.49-8.75; $I^{2}=37 \%$ ) (Fig. 4a). The subgroup analysis of RCTs (561 patients in 3 studies) also reported a significant lower operative time in the suction group (RR 7.13, 95\% CI 3.14-11.12). All patients enrolled in the RCTs underwent a laparoscopic approach (Fig. 4b).

In the laparoscopic group, this outcome was evaluated in 1813 patients ( 5 studies) with the operative time significantly lower in patients who underwent suction only (RR 6.10, 95\% CI 3.34-8.78; $I^{2}=39 \%$ ) (Fig. 4c).

\section{Length of hospital stay}

In the open and laparoscopic group, length of hospital stay was evaluated in 2844 patients ( $1^{2}$ studies). This outcome was lower in patients who underwent peritoneal irrigation and suction, but the result was not statistically significant (MD $-0.39,95 \% \mathrm{CI}-1.07$ to $0.30 ; I^{2}=91 \%$ ) (Fig. 5a). The same result was reported in the subgroup analysis of 1169 patients enrolled in 8 RCTs (MD - 0.70, $95 \% \mathrm{CI}-1.48$ to $0.09 ; I^{2}=85 \%$ ) (Fig. $5 \mathrm{~b}$ ).

In the laparoscopic group, this outcome was studied in 2185 patients (6 studies). The length of stay was lower in patients who underwent peritoneal irrigation and suction, but the result was not statistically significant (MD -0.46 , 95\% CI -1.09 to $0.17 ; I^{2}=88 \%$ ) (Fig. 5c). The analysis of 4 RCTs (673 patients) reported the same result (MD $-0.10,95 \% \mathrm{CI}-0.43$ to $0.24 ; I^{2}=0 \%$ ) (Fig. $5 \mathrm{~d}$ ).

\section{Rate of wound infections}

In the open and laparoscopic group, the rates of wound infection were examined in 2524 patients (10 studies). This complication was lower in patients who underwent suction only, and the result was not statistically significant (MD 1.16, 95\% CI 0.56-2.38; $I^{2}=71 \%$ ). However, the analysis of different age groups shows contrasting results. In the paediatric group, peritoneal irrigation and suction were associated with fewer complications, while in the adult and mixed group suction only seemed to be safer (Fig. 6a). In the subgroup analysis of 1038 patients enrolled in 7 RCTs, there was no difference between the two groups (MD 0.98, 95\% CI 0.42-2.31; $I^{2}=66 \%$ ) (Fig. 6b).

In the laparoscopic group, wound infection was evaluated in 1965 patients (five studies). The rate of this complication was the same in both paediatric and adult groups (MD 1.04, 95\% CI $0.37-2.95 ; I^{2}=66 \%$ ). In the subgroup analysis, there were contrasting results. In the paediatric group, peritoneal irrigation and suction seemed to be related to better outcomes, while in the adult and mixed group, suction only led to a lower complication rate (Fig. 6c). In the subgroup analysis of 453 patients enrolled in 3 RCTs, there was no difference between the two groups (MD 0.88, 95\% CI 0.20-3.87; $I^{2}=0 \%$ ) (Fig. 6d). 


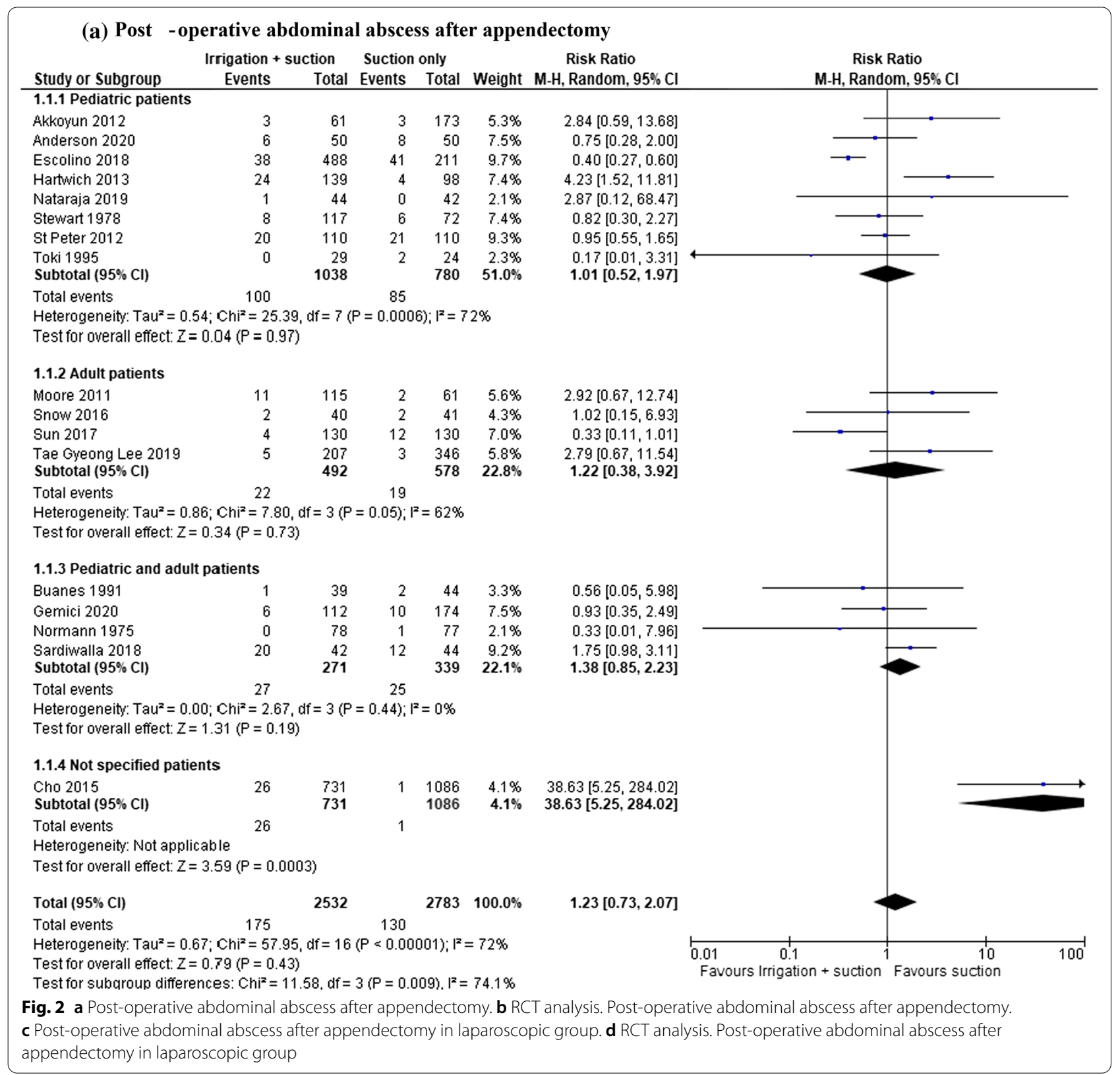

\section{Discussion}

This systematic review with meta-analysis has shown similarity in terms of outcome between the use of peritoneal lavage and suction-only during appendectomy for complicated appendicitis. In particular, our review does not demonstrate a statistical difference in terms of intra-abdominal post-operative abscess, reoperation for abscess, wound infection and hospital stay, between peritoneal irrigation and suction-only of purulent material, in patient underwent appendectomy for complicated appendicitis, laparoscopically or open. Only exception was a lower operative time in suction-only group.
Acute appendicitis is one of the most common gastrointestinal-related diseases, and appendectomy represents one of the most frequently performed abdominal surgical procedures.

Unless appendectomy is considered a safe procedure, it presents an innate risk of complications.

Post-appendectomy complications reported are intraabdominal abscess (IAA), wound infection, wound dehiscence, small bowel obstruction and bleeding. IAA occurs in $2.2 \%$ of cases after laparoscopic appendectomy. In more complicated appendicitis cases, there is a higher risk of development of a post-operative abscess $[7,10]$. 
(b) RCTs analysis. Post-operative abdominal abscess after appendectomy

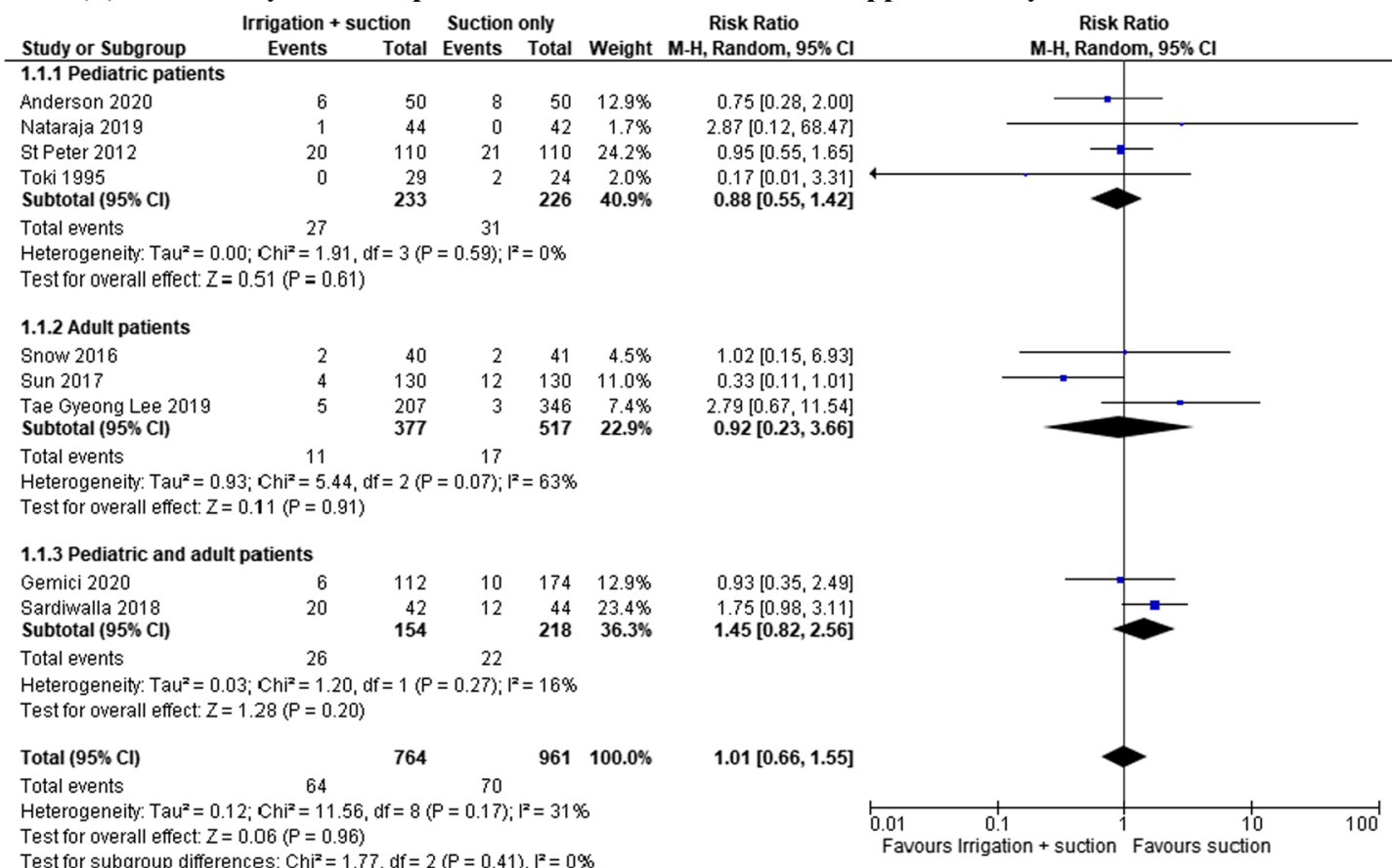

(c) Post-operative abdominal abscess after appendectomy in laparoscopic

$\begin{array}{llll}\text { Irrigation + suction } & \text { Suction only } & \text { Risk Ratio } & \text { Risk Ratio }\end{array}$

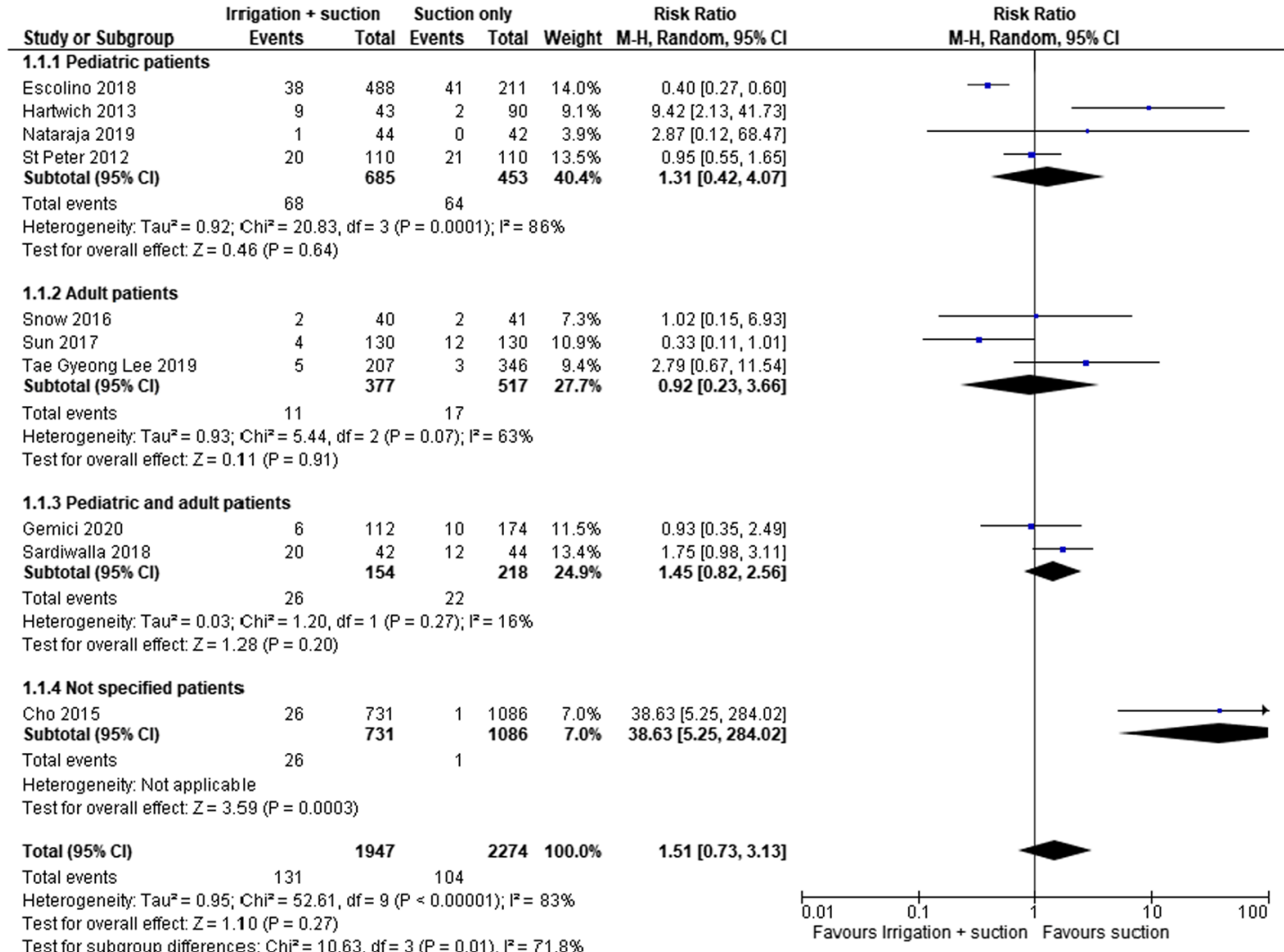

Fig. 2 continued 


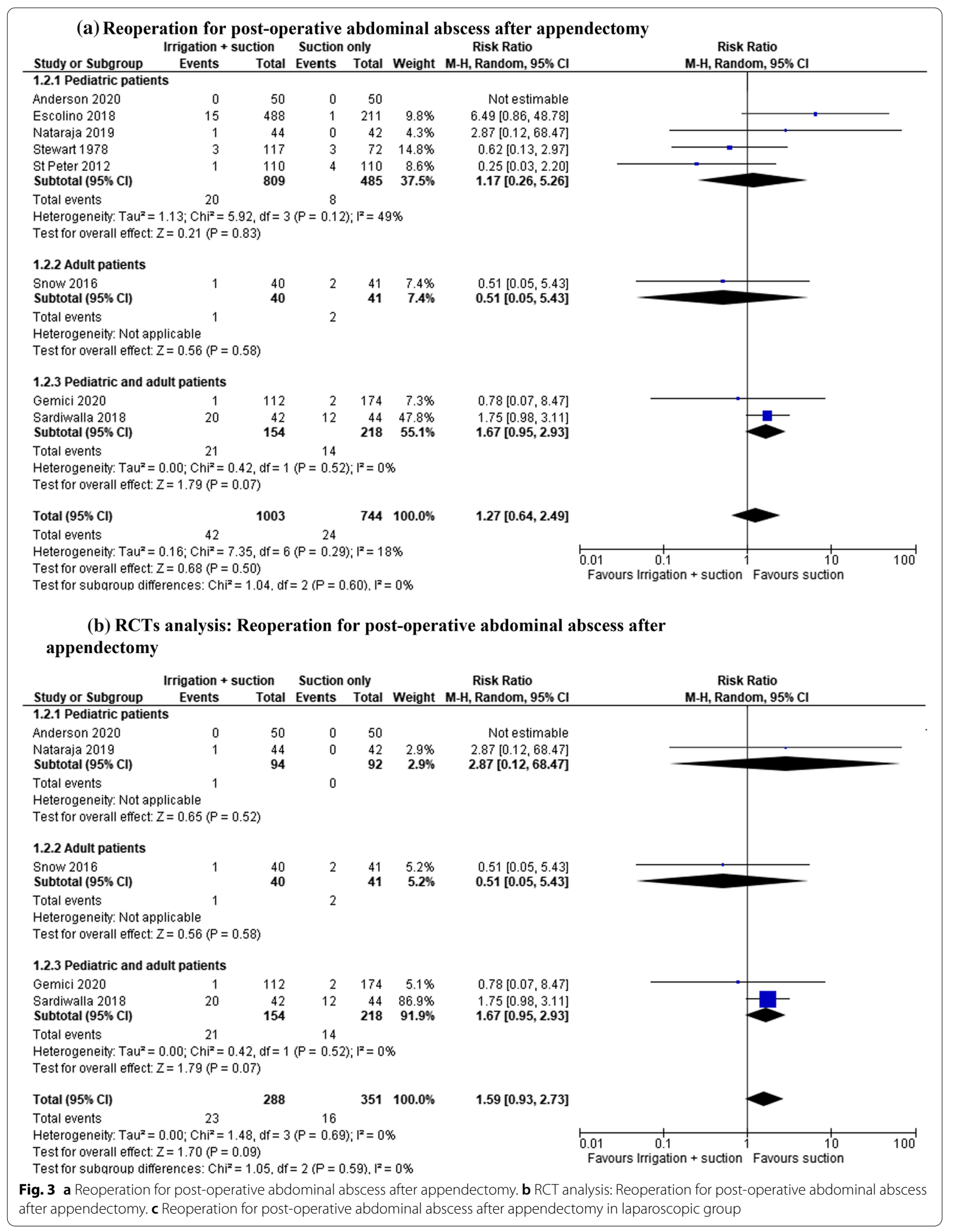


(c) Reoperation for post-operative abdominal abscess after appendectomy in laparoscopic group.

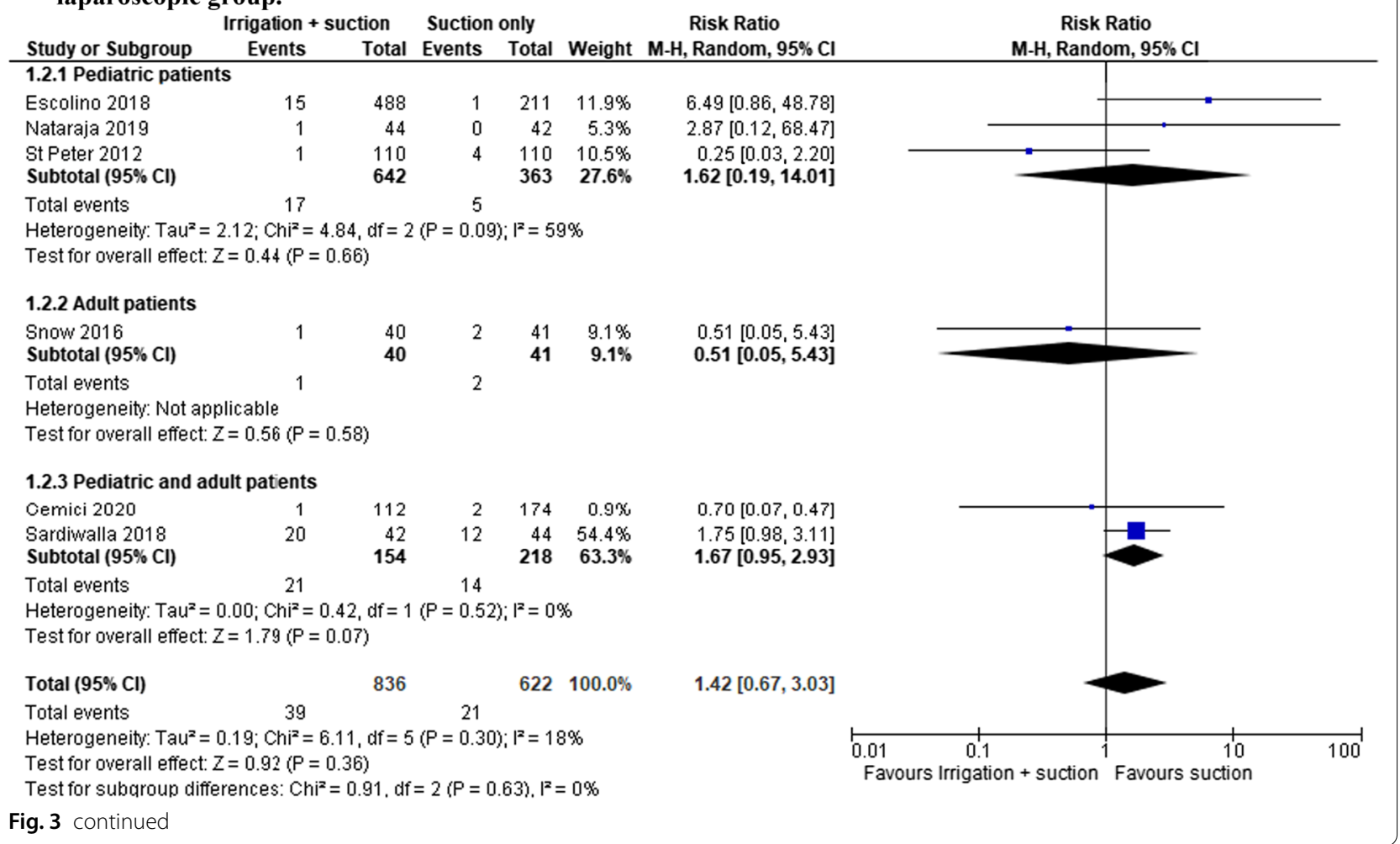

Perforated appendicitis was recognized as an independent risk factor for development of post-operative IAA [79]. Other risk factors are diabetes mellitus, young and old age [8], obesity and peritoneal irrigation [6, 8]. Despite the use of the laparoscopic approach [2], post-operative complications still present with a high incidence rate [61, 62]. The management of IAA remains controversial with different strategies suggested to decrease its incidence. Peritoneal irrigation, first described by Torek in 1903, received great emphasis as a procedure to reduce abscess occurrence. Many studies have been conducted since then, comparing peritoneal irrigation versus suction of peritoneal abscess without lavage, leading to an important heterogeneity of findings and opinions.

We performed a systematic review, according to PRISMA guidelines, comparing seventeen studies with case data for peritoneal irrigation and suction vs suction-only of the abdominal cavity during appendectomy. Analysis included the paediatric population, the adult population and combined age groups. Both laparoscopic and open procedures were included. Occurrence of intraabdominal abscess, reoperation for abscess, operation time, length of stay and wound infections were assessed.

Analysis of the literature revealed early studies which seemed to show the efficiency of peritoneal irrigation in reducing post-operative abscess [10], especially in adult populations. The success of irrigation was thought to be related to bacterial load dilution. More recent studies suggest the ineffectiveness of irrigation in reducing post-operative IAA $[6,8,10]$ as the effect of bacterial load dilution appears to be temporary. Some current evidence indeed suggests that peritoneal irrigation may increase the incidence of abscess formation in perforated appendicitis $[10,55]$.

In 2013, St. Peter defined three mechanisms potentially responsible for the ineffectiveness of peritoneal irrigation:

1. bacteria adhere to the peritoneal mesothelial cells, so irrigations do not decrease the microorganism load on the peritoneum;

2. irrigation may cause diffuse or remote bacterial inoculation, thus spreading the pollution [8];

3. irrigation may dilute mediators of phagocytosis as opsonic proteins and immunoglobulins.

Nevertheless, many surgeons continue to employ peritoneal lavage during appendectomy [63].

A minority of authors only found that peritoneal irrigation could have some benefit in reducing post-operative 


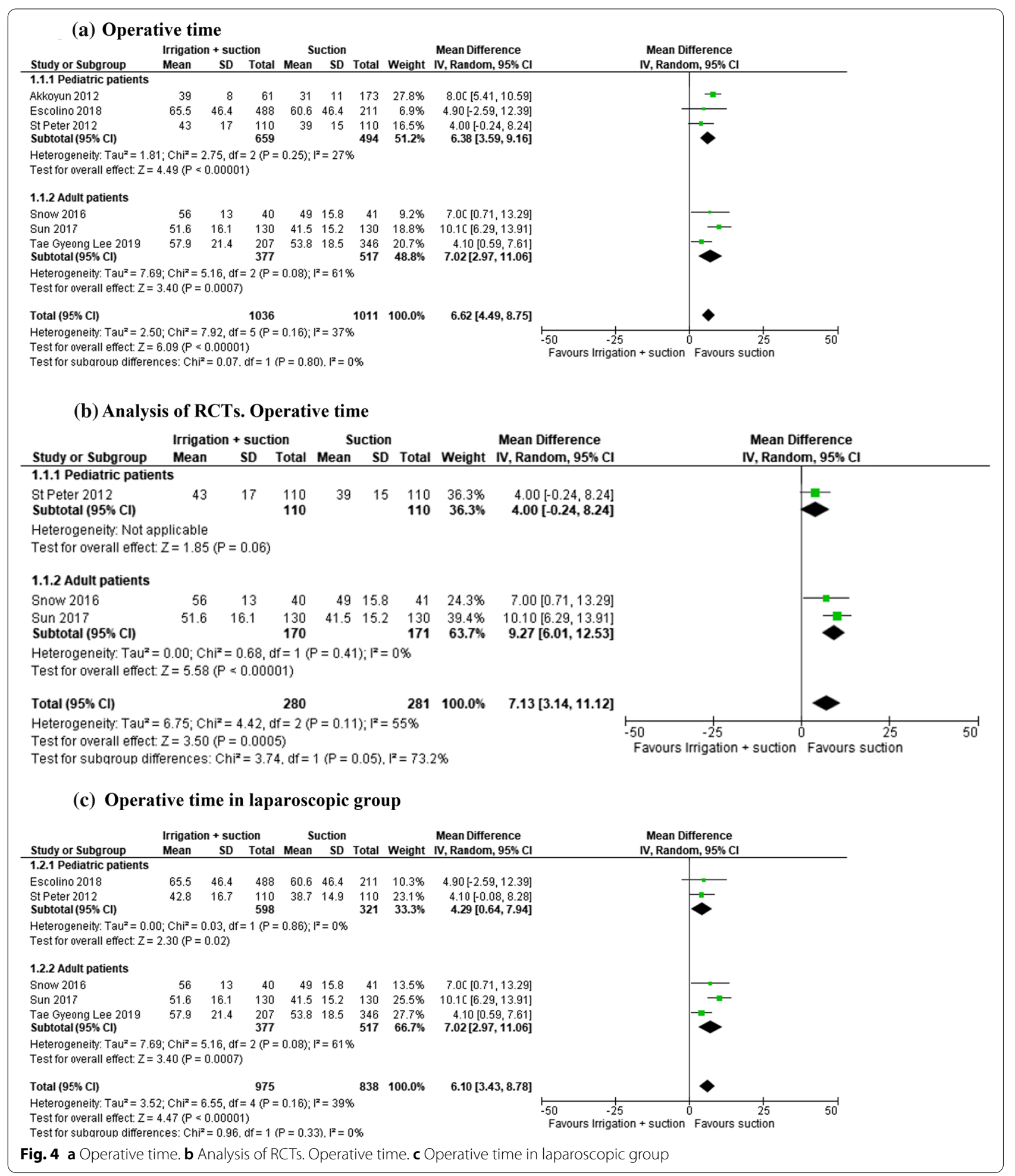

IAA incidence $[51,60]$. Some authors found that peritoneal irrigation seems to increase the risk of developing post-operative IAA after appendectomy, independently from a laparoscopic or open approach $[6,8]$.

Some authors reported differences between irrigation and suction and suction only, especially in children, in 


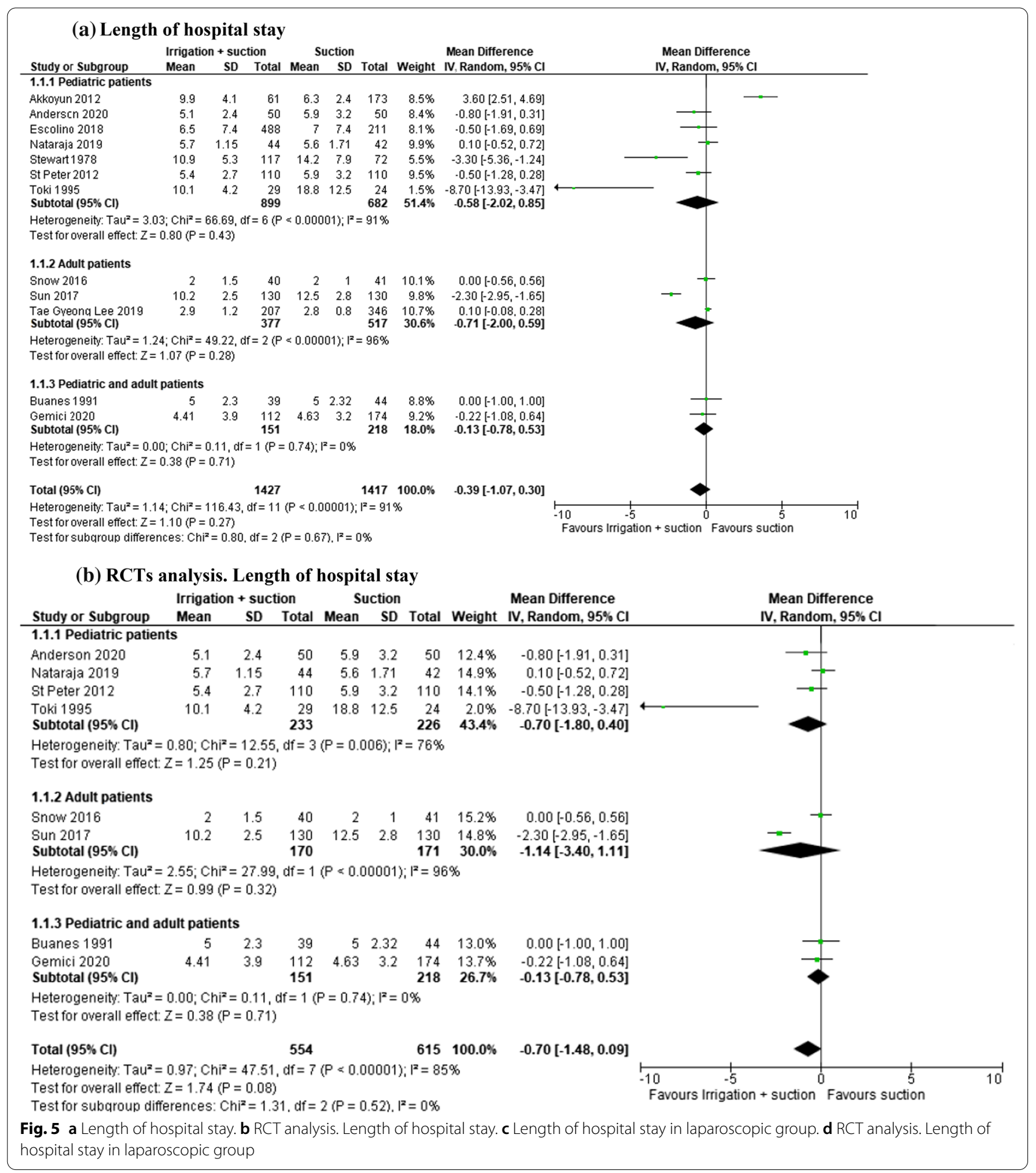

favour of suction only [10, 38]. One study was interrupted due to an excess risk of developing an abscess in the lavage group compared to suction-only group [55].

Most of the analysed studies did not find statistical differences between suction-only versus peritoneal irrigation and suction to prevent post-operative IAA after appendectomy for perforated appendicitis [8].

Many articles have been published around the use of peritoneal irrigation and suction versus suction only during appendectomy. In this wide and heterogeneous 




panorama, no articles succeeded in defining whether irrigation is an effective method to reduce post-operative IAA. Only a few studies suggested that peritoneal irrigation could have some benefit in reducing the incidence of post-operative IAA [51,60], and the other papers reported that peritoneal irrigation seemed to increase the risk of post-operative IAA after appendectomy, regardless of a laparoscopic or open procedure $[6,8]$. Some authors also reported a prolonged operation time in the lavage group.
In this systematic review, we analysed 17 selected studies (9 RCTs and 8 CCTs) with 5315 patients (2532 irrigation and suction vs 2783 irrigation).

We have identified primary (post-operative IAA and reoperation) and secondary outcomes (operative time, length of hospitalization, wound infections).

Regarding primary outcome, in both laparoscopic and open appendectomy, in children and adult population, we found no statistical difference in terms of onset of intraabdominal abscess, although the rate of this complication 


\begin{tabular}{|c|c|c|c|c|c|c|c|c|c|c|}
\hline \multirow[b]{2}{*}{ Study or Subgroup } & \multicolumn{3}{|c|}{$\begin{array}{l}\text { Ts analysis. Lengt } \\
\text { Irrigation + suction }\end{array}$} & \multicolumn{3}{|c|}{$\begin{array}{l}\text { nof hospital sta } \\
\text { Suction }\end{array}$} & \multicolumn{2}{|c|}{$\begin{array}{l}\text { y in laparoscopic group } \\
\text { Mean Difference }\end{array}$} & \multirow{2}{*}{\multicolumn{2}{|c|}{$\begin{array}{l}\text { Mean Difference } \\
\text { IV, Fixed, } 95 \% \mathrm{Cl}\end{array}$}} \\
\hline & Mean & SD & Total & Mean & SD & Total & Weight & IV, Fixed, $95 \% \mathrm{Cl}$ & & \\
\hline \multicolumn{11}{|c|}{ 1.2.1 Pediatric patients } \\
\hline Nataraja 2019 & 5.7 & 1.15 & 44 & 5.6 & 1.71 & 42 & $29.6 \%$ & $0.10[-0.52,0.72]$ & - & \\
\hline $\begin{array}{l}\text { St Peter } 2012 \\
\text { Subtotal }(95 \% \mathrm{Cl})\end{array}$ & 5.4 & 2.7 & $\begin{array}{l}110 \\
154\end{array}$ & 5.9 & 3.2 & $\begin{array}{l}110 \\
152\end{array}$ & $\begin{array}{l}18.5 \% \\
48.2 \%\end{array}$ & $\begin{array}{l}-0.50[-1.28,0.28] \\
-0.13[-0.62,0.35]\end{array}$ & & \\
\hline \multicolumn{11}{|c|}{$\begin{array}{l}\text { Heterogeneity: } \mathrm{Chi}^{2}=1.39, \mathrm{df}=1(\mathrm{P}=0.24) ; \mathrm{I}^{2}=28 \% \\
\text { Test for overall effect: } Z=0.53(\mathrm{P}=0.60)\end{array}$} \\
\hline \multicolumn{11}{|l|}{ 1.2.2 Adult patients } \\
\hline $\begin{array}{l}\text { Snow } 2016 \\
\text { Subtotal }(95 \% \mathrm{Cl})\end{array}$ & 2 & 1.5 & $\begin{array}{l}40 \\
40\end{array}$ & 2 & 1 & $\begin{array}{l}41 \\
41\end{array}$ & $\begin{array}{l}36.6 \% \\
36.6 \%\end{array}$ & $\begin{array}{l}0.00[-0.56,0.56] \\
0.00[-0.56,0.56]\end{array}$ & & \\
\hline \multicolumn{11}{|c|}{$\begin{array}{l}\text { Heterogeneity: Not applicable } \\
\text { Test for overall effect: } Z=0.00(P=1.00)\end{array}$} \\
\hline \multicolumn{11}{|c|}{ 1.2.3 Pediatric and adult patients } \\
\hline $\begin{array}{l}\text { Gemici } 2020 \\
\text { Subtotal }(95 \% \mathrm{Cl})\end{array}$ & 4.41 & 3.9 & $\begin{array}{l}112 \\
112\end{array}$ & 4.63 & 3.2 & $\begin{array}{l}174 \\
174\end{array}$ & $\begin{array}{l}15.2 \% \\
\mathbf{1 5 . 2} \%\end{array}$ & $\begin{array}{l}-0.22[-1.08,0.64] \\
-0.22[-1.08,0.64]\end{array}$ & & \\
\hline \multicolumn{11}{|c|}{$\begin{array}{l}\text { Heterogeneity: Not applicable } \\
\text { Test for overall effect: } Z=0.50(P=0.62)\end{array}$} \\
\hline Total $(95 \% \mathrm{Cl})$ & & & 306 & & & 367 & $100.0 \%$ & $-0.10[-0.43,0.24]$ & & \\
\hline \multicolumn{7}{|c|}{$\begin{array}{l}\text { Heterogeneity: } \mathrm{Chi}^{2}=1.60, \mathrm{df}=3(P=0.66) ;\left.\right|^{2}=0 \% \\
\text { Test for overall effect: } Z=0.56(P=0.57) \\
\text { Test for subqroup differences: } C h i^{2}=0.21, \mathrm{df}=2(P=0.90), \mathrm{I}^{2}=0 \%\end{array}$} & & & \begin{tabular}{lcc|cc}
-10 & -5 & 1 & 5 \\
Favours & -5 & 5 \\
\end{tabular} & 10 \\
\hline Fig. 5 continued & & & & & & & & & & \\
\hline
\end{tabular}

appeared to be lower in patients who underwent suction only.

Same results for reoperation for post-operative abscess: a lower rate was registered in patients who underwent suction only; however, the results were not statistically significant, in both open and laparoscopic groups.

For secondary outcome, in the open and laparoscopic groups, operative time was reported as significantly lower in patients who underwent suction only.

In the open and laparoscopic group, length of hospital stay was lower in patients who underwent peritoneal irrigation and suction, but the result was not statistically significant.

In the open and laparoscopic group, the rates of wound infection were lower in patients who underwent suction only, although the result was not statistically significant. However, the analysis of different age groups shows contrasting results. In the paediatric group, peritoneal irrigation and suction were associated with fewer complications, while in the adult and mixed group suction only seemed to be safer.

Unfortunately, these publications are not homogeneous as some of them analyse a laparoscopic approach only, other just open procedure or other both of them. The population studied were also different: some articles analyse paediatric population, instead other adult population or both.

The risk of bias in the RCTs was assessed using methods described in the Cochrane Handbook for Systematic Reviews of Interventions and the Risk of Bias In
Non-randomized Studies of Interventions (ROBINS-I) assessment tool.

The risk of bias was reported as low to moderate.

According to ROBINS-I tool, three studies were assessed as low risk of overall bias, while five were determined to have a moderate risk. Regarding bias due to confounding, four studies were evaluated as having a low risk, four studies seemed to have a moderate risk of bias due to confounding. Regarding bias in classification of the interventions, all studies had a low risk. Outcomes were clearly defined and measures were not influenced by knowledge of the intervention received. The methods of outcome assessment were comparable across intervention groups, and no systematic errors were detected. Analysing bias due to missing data, three reviews were assessed as moderate risk.

This systematic review and meta-analysis has failed to demonstrate the superiority of employing intra-operative peritoneal irrigation and suction over suction-only to reduce the rate of post-operative intra-abdominal abscess after appendectomy (RR 1.23, 95\% CI 0.73-2.07; $\left.I^{2}=72 \%\right)$. Furthermore, the absolute number of abscesses was fewer in suction-only groups both in the overall procedure group $(6.91 \%, 175 / 2532$, in lavage group vs $4.67 \%, 130 / 2783$, in suction group) and in laparoscopic procedures $(6.73 \%, 131 / 1947$, in lavage group vs $4.57 \%$, $104 / 2274$, in suction group). The subgroup analysis based on patient age yielded the same results.

Operation time (RR 6.10, 95\% CI 3.34-8.78; $I^{2}=39 \%$ ) and rate of reoperation ( $\mathrm{RR} 6.62,95 \%$ CI 4.49-8.75; 


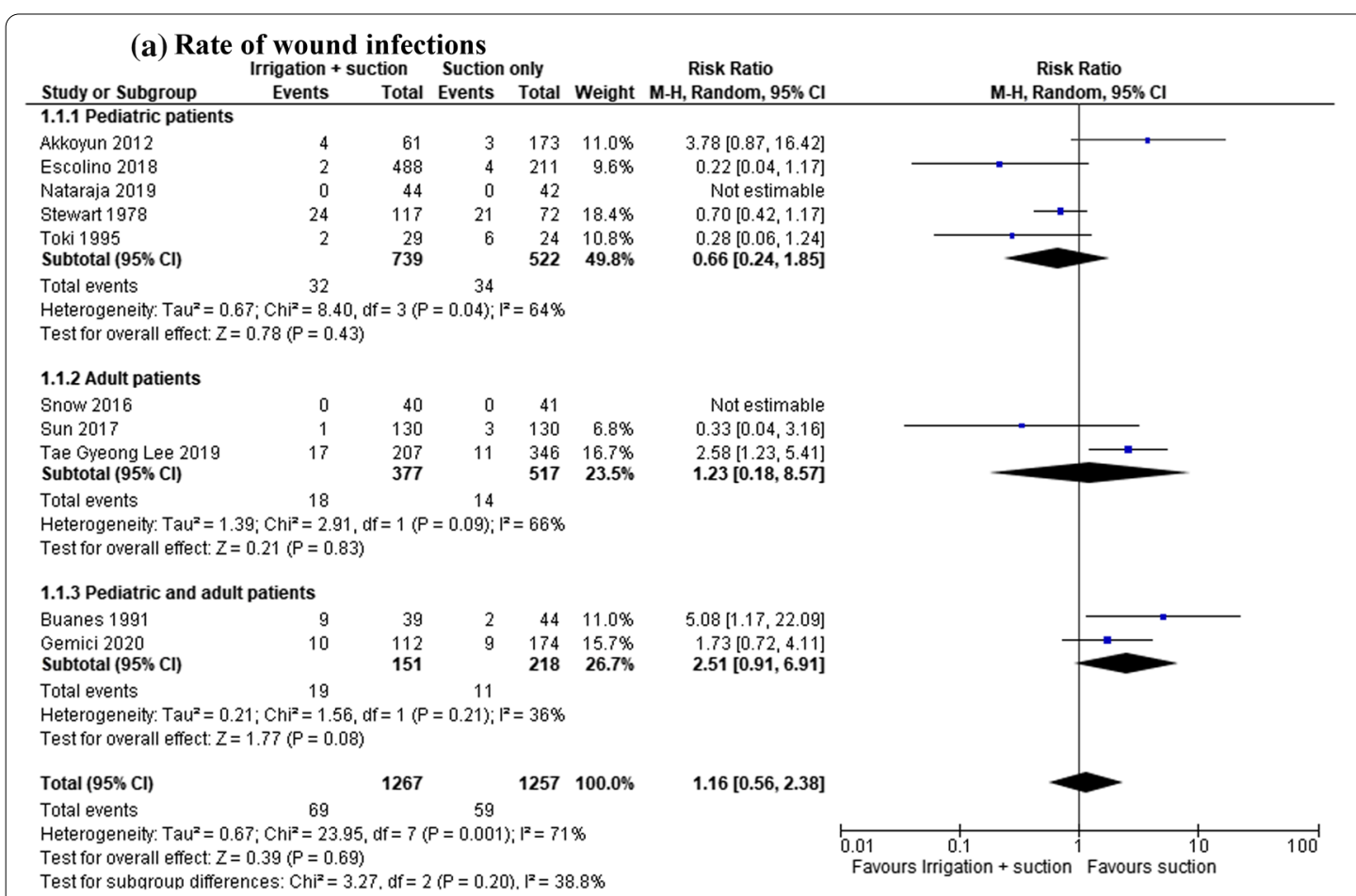

(b)RCT analysis: Rate of wound infections



Test for subaroup differences: $\mathrm{Ch}^{2}=5.99 . \mathrm{df}=2(\mathrm{P}=0.05), \mathrm{I}^{2}=66.6 \%$

Fig. 6 a Rate of wound infections. b RCT analysis: rate of wound infections. c Rate of wound infections in laparoscopic group. $\mathbf{d}$ RCT analysis. Rate of wound infections in laparoscopic group 


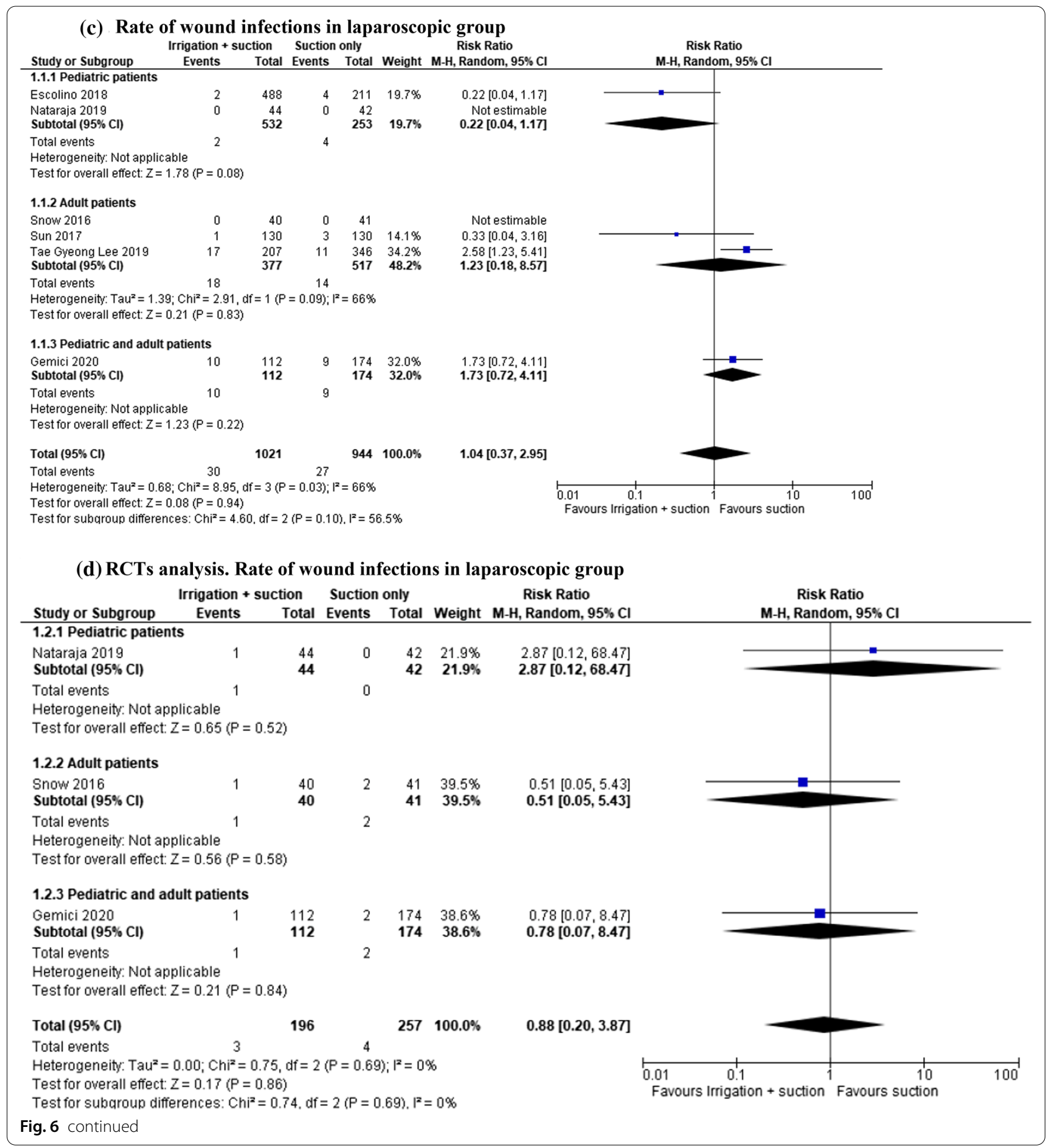

$\left.I^{2}=37 \%\right)$ were significantly lower in patients who underwent suction only.

In the paediatric populations, the lavage groups showed some advantage with regard to the incidence of wound infection for laparoscopic appendectomy, although this was not statistically significant (MD 1.16, 95\% CI 0.56$\left.2.38 ; I^{2}=71 \%\right)$.
Overall no statistical significance was found in the defined primary and secondary outcomes, except for operation time, between peritoneal irrigation and suction group compared to suction only in treating complicated appendicitis. Clinical advantages, which were not statistically significant, for reduced incidence of post-operative intra-abdominal abscess and reoperation for abscess, 
operative time and wound infection were detected in the suction-only groups.

\section{Conclusion}

In conclusion, our analysis did not find a statistical advantage in terms of major outcome in the use of intraoperative peritoneal irrigation on the avoidance of IAA, neither were disadvantages detected. Nevertheless, many articles reported clinical evidence of benefit in the suction-only groups for treating complicated appendicitis in reducing post-operative risk of abscess, wound infection and operative times. This meta-analysis suggests the use of an only-suction approach of purulent liquid in cases of localized peritonitis during appendectomy. In the presence of diffuse purulent peritonitis, a prolonged lavage until the abdomen is completed cleansed may still be preferable.

\section{Abbreviations}

RCT: Randomized, controlled trial; CCT: Controlled clinical trials; PRISMA: Preferred Reporting Items for Systematic Reviews and Meta-analyses; IAA: Intra-abdominal abscess; WSES: World Society of Emergency Surgery; BMI: Body mass index; RR: Risk ratios.

\section{Supplementary Information}

The online version contains supplementary material available at https://doi. org/10.1186/s13017-021-00391-y.

\section{Additional file 1. SDC searches.}

Additional file 2: Table S1. Excluded studies.

Additional file 3: SDC baseline.

Additional file 4: SDC 3a: Risk-of-bias graph: review authors'judgments about each risk-of-bias item presented as percentages across all included studies.

Additional file 5: SDC 3b: Risk-of-bias summary: review authors'judgments about each risk-of-bias item for includedstudies.

Additional file 6: SDC 4: Risk of bias domains.

\section{Acknowledgements}

Not applicable.

\section{Authors' contributions}

All authors equally contributed. Full texts were independently screened by two authors (S.V. and R.C.), and a final consensus was reached by the same authors. No disagreements were reported. All authors read and approved the final manuscript.

\section{Funding}

Not support received for the research.

\section{Availability of data and materials}

The literature was searched using PubMed, Scopus and Web of Science. Code availability: PROSPERO international prospective register of systematic reviews, Number CRD42020186848.

\section{Declarations}

Ethics approval and consent to participate

Not applicable.

\section{Consent for publication}

Not applicable.

\section{Competing interests}

None to declare.

\section{Author details}

${ }^{1}$ General and Emergency Surgical Clinic of Ancona, Ancona, Italy. ${ }^{2}$ Department of Pediatric Surgery, Meyer Children's Hospital, University of Florence, Florence, Italy. ${ }^{3}$ Hospital of Terni, Terni, Italy. ${ }^{4}$ Department of Colorectal Surgery, Addenbrooke's Hospital, Cambridge University Hospitals NHS Foundation Trust, Hills Road, Cambridge CB2 0QQ, UK. ${ }^{5}$ Department of Pediatric Surgery, Meyer Children's Hospital, School of Environment and Life Science, University of Salford, Salford, UK. ${ }^{6}$ Department of Surgery, University of Rome, Sapienza, Italy. ${ }^{7}$ Department of Medicine and Surgery, University of Perugia, Perugia, Italy. ${ }^{8}$ Department of Pediatric Surgery, Meyer Children's Hospital, Department of Neurofarba, University of Florence, Florence, Italy.

Received: 26 May 2021 Accepted: 19 August 2021

Published online: 06 September 2021

References

1. Addiss DG, Shaffer N, Fowler BS, Tauxe RV. The epidemiology of appendicitis and appendectomy in the United States. Am J Epidemiol. 1990;132:910-25.

2. Sauerland S, Lefering R, Neugebauer EA. Laparoscopic versus open surgery for suspected appendicitis. Cochrane Database Syst Rev. 2002:1:CD001546.

3. Sartelli M, Baiocchi GL, Di Saverio S, Ferrara F, Labricciosa FM, Ansaloni L, Coccolini F, et al. Prospective observational study on acute appendicitis worldwide (POSAW). World J Emerg Surg. 2018;13:19.

4. Nataraja RM, Panabokke G, Chang AD, Mennie N, Tanny ST, Keys C, Cheng W, Pacilli M, Ferguson P. Does peritoneal lavage influence the rate of complications following pediatric laparoscopic appendicectomy in children with complicated appendicitis? A prospective randomized clinical trial. J Pediatr Surg. 2019;54(12):2524-7. https://doi.org/10.1016/j.jpedsurg.2019. 08.039.

5. St. Peter SD, Sharp SW, Holcomb GW 3rd, Ostlie DJ. An evidence-based definition for perforated appendicitis derived from a prospective randomized trial. J Pediatr Surg. 2008;43:2242-5.

6. Cho J, Park I, Lee D, Sung K, Baek J, Lee J. Risk factors for postoperative intra-abdominal abscess after laparoscopic appendectomy: analysis for consecutive 1817 experiences. Dig Surg. 2015;32(5):375-81. https://doi. org/10.1159/000438707.

7. Levin DE, Pegoli W Jr. Abscess after appendectomy: predisposing factors. Adv Surg. 2015;49:263-80.

8. Moore CB, Smith RS, Herbertson R, Toevs C. Does use of intraoperative irrigation with open or laparoscopic appendectomy reduce post-operative intra-abdominal abscess? Am Surg. 2011;77(1):78-80.

9. Krisher SL, Browne A, Dibbins A, Tkacz N, Curci M. Intraabdominal abscess after laparoscopic appendectomy for perforated appendicitis. Arch Surg. 2001:136:438-41.

10. Hartwich JE, Carter RF, Wolfe L, Goretsky M, Heath K, St. Peter SD, Lanning DA. The effects of irrigation on outcomes in cases of perforated appendicitis in children. J Surg Res. 2013;180(2):222-5. https://doi.org/10.1016/j. jss.2012.04.043.

11. Esposito C, Calvo A, Castagnetti M, Alicchio F, Suarez C, Giurin I, Settimi A. Open versus laparoscopic appendicectomy in the pediatric population: a literature review and analysis of complications. J Laparoendosc Adv Surg Tech A. 2012;22:834-9.

12. Tanaka S, Kubota D, Lee SH, Oba K, Matsyama M. Effectiveness of laparoscopic approach for acute appendicitis. Osaka City Med J. 2007;53:1-8. 
13. Guller U, Hervey S, Purves H, Muhlbaier LH, Peterson ED, Eubanks S, et al. Laparoscopic versus open appendectomy: outcomes comparison based on a large administrative database. Ann Surg. 2004;239:43-52.

14. Katkhouda N, Mason RJ, Towfigh S, Gevorgyan A, Essani R. Laparoscopic versus open appendectomy: a prospective randomized doubleblind study. Ann Surg. 2005;242:439-48.

15. Yau KK, Siu WT, Tang CN, Yang GP, Li MK. Laparoscopic versus open appendectomy for complicated appendicitis. J Am Coll Surg. 2007;205:60-5.

16. Asarias JR, Schlussel AT, Cafasso DE, et al. Incidence of postoperative intraabdominal abscesses in open versus laparoscopic appendectomies. Surg Endosc. 2011;25:2678-83.

17. Nataraja RM, Teague WJ, Galea J, et al. Comparison of intraabdominal abscess formation after laparoscopic and open appendectomy in children. J Pediatr Surg. 2012;47:317-21.

18. Newman K, Ponsky T, Kittle K, et al. Appendicitis 2000: variability in practice, outcomes, and resource utilization at thirty pediatric hospitals. J Pediatr Surg. 2003;38:372-9.

19. Bi LW, Yan BL, Yang QY, Cui HL. Peritoneal irrigation vs suction alone during pediatric appendectomy for perforated appendicitis: a metaanalysis. Medicine (Baltimore). 2019;98(50):e18047.

20. Fike FB, Mortellaro VE, Juang D, et al. The impact of postoperative abscess formation in perforated appendicitis. J Surg Res. 2011;170:24-6.

21. Horan TC, Gaynes RP, Martone WJ, et al. CDC definitions of nosocomial surgical site infections, 1992: a modification of CDC definitions of surgical wound infections. Am J Infect Control. 1992;20:271-4.

22. Markar SR, Blackburn S, Cobb R, et al. Laparoscopic versus open appendectomy for complicated and uncomplicated appendicitis in children. J Gastrointest Surg. 2012;16:1993-2004.

23. Montravers $\mathrm{P}$, Dupont $\mathrm{H}$, Leone $\mathrm{M}$, et al. Guidelines for management of intra-abdominal infections. Anaesth Crit Care Pain Med. 2015:34:117-30.

24. Solomkin JS, Mazuski JE, Bradley JS, et al. Diagnosis and management of complicated intra-abdominal infection in adults and children: guidelines by the Surgical Infection Society and the Infectious Diseases Society of America. Clin Infect Dis. 2010;50:133-64.

25. Sabbagh C, Siembida N, Dupont H, Diouf M, Schmit JL, Boddaert S, Regimbeau JM. The value of post-operative antibiotic therapy after laparoscopic appendectomy for complicated acute appendicitis: a prospective, randomized, double-blinded, placebo-controlled phase III study (ABAP study). Trials. 2020;21(1):451.

26. Thom H, Norman G, Welton NJ, Crosbie EJ, Blazeby J, Dumville JC. Intracavity lavage and wound irrigation for prevention of surgical site infection: systematic review and network meta-analysis. Surg Infect (Larchmt). 2020. https://doi.org/10.1089/sur.2019.318.

27. Agresta F, Ansaloni L, Baiocchi GL, Bergamini C, Campanile FC, Carlucci $\mathrm{M}$, et al. Laparoscopic approach to acute abdomen from the Consensus Development Conference of the Società Italiana di Chirurgia Endoscopica e nuove tecnologie (SICE), Associazione Chirurghi Ospedalieri Italiani (ACOI), Società Italiana di Chirurgia (SIC), Società Italiana di Chirurgia d'Urgenza e del Trauma (SICUT), Società Italiana di Chirurgia nell'Ospedalità Privata (SICOP), and the European Association for Endoscopic Surgery (EAES). Surg Endosc. 2012;26(8):2134-64.

28. Di Saverio S, Podda M, De Simone B, Ceresoli M, Augustin G, Gori A, et al. Diagnosis and treatment of acute appendicitis: 2020 update of the WSES Jerusalem guidelines. World J Emerg Surg. 2020;15(1):27.

29. Lin HF, Lai HS, Lai IR. Laparoscopic treatment of perforated appendicitis. World J Gastroenterol. 2014;20(39):14338-47. https://doi.org/10.3748/ wjg.v20.i39.14338.

30. Shea BJ, Reeves BC, Wells G, Thuku M, Hamel C, Moran J, et al. AMSTAR 2: a critical appraisal tool for systematic reviews that include randomised or non-randomised studies of healthcare interventions, or both. BMJ (Online). 2017;358:1.

31. Moher D, Liberati A, Tetzlaff J, Altman DG. Preferred reporting items for systematic reviews and meta-analyses: the PRISMA statement. J Clin Epidemiol. 2009;62(10):1006-12.

32. Higgins JPT, Thomas J, Chandler J, Cumpston M, Li T, Page MJ, Welch VA (eds). Cochrane handbook for systematic reviews of interventions version 6.1 (updated September 2020); 2020. Cochrane. www.training.cochrane. org/handbook.
33. Sterne JA, Hernán MA, Reeves BC, Savović J, Berkman ND, Viswanathan M, et al. ROBINS-I: a tool for assessing risk of bias in non-randomised studies of interventions. BMJ. 2016;355:i4919.

34. McGuinness LA, Higgins JPT. Risk-of-bias VISualization (robvis): an R package and Shiny web app for visualizing risk-of-bias assessments. Research Synthesis Methods; 2020.

35. Mantel N, Haenszel W. Statistical aspects of the analysis of data from retrospective studies of disease. JNCI J Natl Cancer Inst. 1959;22(4):719-48.

36. Rücker G, Schwarzer G, Carpenter JR, Schumacher M. Undue reliance on 12 in assessing heterogeneity may mislead. BMC Med Res Methodol. 2008;8(1):79.

37. Kontopantelis E, Springate DA, Reeves D. A re-analysis of the Cochrane Library data: the dangers of unobserved heterogeneity in meta-analyses. PLOS ONE. 2013;8(7):69930.

38. Siotos C, Stergios K, Prasath V, Seal SM, Duncan MD, Sakran JV, Habibi M. Irrigation versus suction in laparoscopic appendectomy for complicated appendicitis: a meta-analysis. J Surg Res. 2019;235:237-43.

39. Gammeri E, Petrinic T, Bond-Smith G, Gordon-Weeks A. Meta-analysis of peritoneal lavage in appendicectomy. BJS Open. 2018;3(1):24-30.

40. Hajibandeh S, Hajibandeh S, Kelly A, Shah J, Khan RMA, Panda N, Mansour M, Malik S, Dalmia S. Irrigation versus suction alone in laparoscopic appendectomy: is dilution the solution to pollution? A systematic review and meta-analysis. Surg Innov. 2018;25(2):174-82.

41. Schwarz A, Bölke E, Peiper M, Esch JA, Steinbach G, van Griensven M, Orth K. Inflammatory peritoneal reaction after perforated appendicitis: continuous peritoneal lavage versus non lavage. Eur J Med Res. 2007; 12(5):200-5

42. Schneider A, Sack U, Rothe K, Bennek J. Peritoneal taurolidine lavage in children with localised peritonitis due to appendicitis. Pediatr Surg Int. 2005;21(6):445-8.

43. Bölke E, Jehle PM, Schwarz A, Brückner U, Nothnagel B, Kelbel I, SugerWideck H, Storck M, Steinbach G, Trautmann M, Orth K. Therapie der diffusen eitrigen Peritonitis mit kontinuierlicher Peritoneallavage [Therapy of diffuse suppurative peritonitis with continuous peritoneal lavage]. Wien Klin Wochenschr. 2002;114(15-16):709-16.

44. Gruel Y, Bourdelat D, Guibert L, Bracq H, Babut JM. Lavage péritonéal per-opératoire dans les péritonites d'origine appendiculaire de l'enfant. A propos de cinquante cas [Peroperative peritoneal lavage in peritonitis of appendicular origin in children. Apropos of 50 cases]. Ann Chir. 1985;39(5):305-8

45. Udén P, Eskilsson P, Brunes L, Mätzsch T. A clinical evaluation of postoperative peritoneal lavage in the treatment of perforated appendicitis. $\mathrm{Br} J$ Surg. 1983;70(6):348-9.

46. Tighe B, Anderson M, Dooley C, Egan T, Domhnaill SO, Delaney PV. Betadine irrigation following appendicectomy - a randomized prospective trial. Ir Med J. 1982;75(3):96.

47. Gjessing J, Tomlin PJ. Acute appendicitis and continuous peritoneal lavage. Anaesth Intensive Care. 1976;4(4):347-50.

48. Akkoyun I, Tuna AT. Advantages of abandoning abdominal cavity irrigation and drainage in operations performed on children with perforated appendicitis. J Pediatr Surg. 2012;47(10):1886-90. https://doi.org/10. 1016/j.jpedsurg.2012.03.049.

49. Anderson KT, Putnam LR, Bartz-Kurycki MA, Hamilton EC, Yafi M, Pedroza C, Austin MT, Kawaguchi AL, Kao LS, Lally KP, Tsao K. Povidone-iodine irrigation for pediatric perforated appendicitis may be protective: a Bayesian pilot randomized controlled trial. Ann Surg. 2020;271(5):827-33. https:// doi.org/10.1097/SLA.0000000000003398.

50. Buanes TA, Andersen GP, Jacobsen U, Nygaard K. Perforated appendicitis with generalized peritonitis. Prospective, randomized evaluation of closed postoperative peritoneal lavage. Eur J Surg. 1991;157(4):277-9.

51. Escolino M, Becmeur F, Saxena A, Till H, Masieri L, Cortese G, Holcomb GW 3rd, Esposito C. Infectious complications after laparoscopic appendectomy in pediatric patients with perforated appendicitis: is there a difference in the outcome using irrigation and suction versus suction only? Results of a multicentric international retrospective study. J Laparoendosc Adv Surg Tech A. 2012;28(10):1266-70. https://doi.org/10.1089/lap. 2018.0061.

52. Gemici E, Bozkurt MA, Sürek A, Seyhun C, Güneş ME. Laparoscopic lavage versus aspiration alone in perforated acute appendicitis: a prospective randomized controlled study. Surg Laparosc Endosc Percutan Tech. 2020;30(1):14-7. https://doi.org/10.1097/SLE.0000000000000745. 
53. Lee TG, Nam S, Lee HS, Lee JH, Hong YK, Kang JG. Irrigation versus suction alone during laparoscopic appendectomy for uncomplicated acute appendicitis. Ann Coloproctol. 2020;36(1):30-4. https://doi.org/10.3393/ ac.2019.06.25.

54. Normann E, Korvald E, Lotveit T. Perforated appendicitis—lavage or drainage? Ann Chir Gynaecol Fenn. 1975;64(4):195-7.

55. Sardiwalla II, Modise KZ. Laparoscopic lavage versus suction only in complicated acute appendicitis: a prospective randomized control trial. Int Surg. 2018;103(7-8):371-7. https://doi.org/10.9738/INTSU RG-D-18-00025.1.

56. Snow HA, Choi JM, Cheng MW, Chan ST. Irrigation versus suction alone during laparoscopic appendectomy; a randomized controlled equivalence trial. Int J Surg. 2016;28:91-6. https://doi.org/10.1016/j.ijsu.2016.01. 099.

57. St. Peter SD, Adibe OO, lqbal CW, Fike FB, Sharp SW, Juang D, Lanning D, Murphy JP, Andrews WS, Sharp RJ, Snyder CL, Holcomb GW, Ostlie DJ. Irrigation versus suction alone during laparoscopic appendectomy for perforated appendicitis: a prospective randomized trial. Ann Surg. 2012;256(4):581-5. https://doi.org/10.1097/SLA.0b013e31826a91e5 (PMID: 22964730)

58. Stewart DJ, Matheson NA. Peritoneal lavage in appendicular peritonitis. $\mathrm{Br}$ J Surg. 1978;65(1):54-6. https://doi.org/10.1002/bjs.1800650115.
59. Sun F, Wang $H$, Zhang F, Zhang $X$, Xing Z, Zhang $S$, Zhang H, Wang $Y$. Copious irrigation versus suction alone during laparoscopic appendectomy for complicated appendicitis in adults. J Investig Surg. 2018;31(4):342-6. https://doi.org/10.1080/08941939.2017.1319995.

60. Toki A, Ogura K, Horimi T, Tokuoka H, Todani T, Watanabe Y, Uemura S, Urushihara N, Noda T, Sato Y, et al. Peritoneal lavage versus drainage for perforated appendicitis in children. Surg Today. 1995;25(3):207-10. https://doi.org/10.1007/BF00311528.

61. Fishman SJ, Pelosi L, Klavon SL, et al. Perforated appendicitis: prospective outcome analysis for 150 children. J Pediatr Surg. 2000;35(6):923-6.

62. Morrow SE, Newman KD. Current management of appendicitis. Semin Pediatr Surg. 2007;16:34-40.

63. Mogilner JG, Slijper N, Kandelis E, et al. The management of pediatric appendicitis: an opinion survey of Israeli pediatric surgeons. Harefuah. 2007;146:414-9.

\section{Publisher's Note}

Springer Nature remains neutral with regard to jurisdictional claims in published maps and institutional affiliations.
Ready to submit your research? Choose BMC and benefit from:

- fast, convenient online submission

- thorough peer review by experienced researchers in your field

- rapid publication on acceptance

- support for research data, including large and complex data types

- gold Open Access which fosters wider collaboration and increased citations

- maximum visibility for your research: over $100 \mathrm{M}$ website views per year

At $\mathrm{BMC}$, research is always in progress.

Learn more biomedcentral.com/submissions 